\title{
The genetic base of Brazilian soybean cultivars: evolution over time and breeding implications
}

\author{
Philip Traldi Wysmierski and Natal Antonio Vello \\ Departamento de Genética, Escola de Agricultura "Luiz de Queiroz", Universidade de São Paulo, \\ Piracicaba, SP, Brazil.
}

\begin{abstract}
Genetic diversity is essential for crop breeding and one way to estimate it is through the concept of genetic base, which can be defined as the number of ancestors and their relative genetic contributions (RGC) to each cultivar. The RGC can be estimated through the coefficient of parentage between the ancestors and cultivars. Previous studies determined that the genetic base of Brazilian soybean was very narrow. The objective of this work was to evaluate the pedigree of 444 Brazilian soybean cultivars to estimate their genetic base. The cultivars were divided according to their release dates and according to their origin (public or private), and the genetic base for each group was also estimated. We found 60 ancestors, of which the top four (CNS, S-100, Roanoke and Tokyo, respectively) contribute $55.3 \%$ of the genetic base. Only 14 ancestors have an RGC over $1.0 \%$, and they represent $92.4 \%$ of the genetic base. Analysis of the release dates indicated that there has been an increase in the number of ancestors over time, but the four main ancestors were the same over all periods, and their cumulative RGC increased from $46.6 \%$ to $57.6 \%$, indicating a narrowing of the genetic base.
\end{abstract}

Keywords: genetic base, Glycine max, coefficient of parentage, genetic vulnerability.

Received: May 3, 2013; Accepted: August 5, 2013.

\section{Introduction}

Soybean is one of the most important field crops in the world, and Brazil is the second largest producer and exporter of this commodity, behind the United States. The main countries which import soybean from Brazil are China (22,885,887 t), Spain $(2,155,811 \mathrm{t})$, the Netherlands $(1,036,919$ t), Japan $(548,339$ t), Germany $(522,354 \mathrm{t})$ and France $(506,775 \mathrm{t})$. This crop was introduced into Brazil around the end of the nineteenth century. It gained economic importance during the 1970 s and has been increasing ever since. In 2011/2012, 25 million ha of soybean were planted, which corresponds to almost half (49.2\%) of the total area of field crops in the country, achieving a total production of 66 million metric tons and a mean yield of 2651 $\mathrm{kg} / \mathrm{ha}$ (Conab, 2013).

The first soybean cultivars planted during the 1960s and 1970s were introduced from the South of the United States, e.g. Bragg, Davis, and Lee. With the growing importance of soybean, breeders began crossing these cultivars among themselves and with other sources, obtaining the first Brazilian cultivars, such as Industrial, Santa Rosa and Campos Gerais.

Send correspondence to Philip T. Wysmierski. Departamento de Genética, Escola de Agricultura "Luiz de Queiroz", Universidade de São Paulo, Av. Pádua Dias n. 11, 13418-900 Piracicaba, SP, Brazil. E-mail: philiptraldi@yahoo.com.br, philiptraldiw@usp.br.
The frequent crossing of a small number of cultivars can lead to a reduction in genetic diversity. One way to measure the genetic diversity of a crop is through the concept of genetic base, which can be defined as the number of ancestors and their relative genetic contribution (RGC) to a specific group (Cui et al., 2000a). The term ancestor usually refers to a founding stock with no known pedigree (Gizlice et al., 1994). The RGC can be estimated through the mean coefficient of parentage (COP) between all the cultivars and an ancestor. This method has been used in many studies, and it is applicable when there are detailed pedigree records available. The genetic base of Brazilian cultivars was estimated by Hiromoto and Vello (1986), who analyzed 69 cultivars. They found only 26 ancestors, of which the main four ancestors (CNS, Roanoke, Tokyo and S-100) contributed $48.2 \%$ of the genetic base, and they concluded that it is narrow. The Brazilian and North American soybean genetic bases also shared six important ancestors. The genetic base for soybean cultivars has been estimated for the United States (Delannay et al., 1983; Gizlice et al., 1994; Sneller, 1994, 2002), China (Cui et. al., 2000a), Japan (Zhou et al., 2000) and India (Bharadwaj, 2002). China has the largest genetic base, with 339 ancestors, while other countries have smaller ones (Table 1).

Since the study by Hiromoto and Vello (1986) there have been no large scale attempts to quantify the genetic base of Brazilian soybean cultivars and to analyze its evolu- 
Table 1 - Comparison among the soybean genetic base of different countries based on the number of cultivars to equal or surpass a specific AGC, number of ancestors, number of cultivars analyzed, mean COP and period analyzed.

\begin{tabular}{|c|c|c|c|c|c|c|c|}
\hline \multirow[t]{2}{*}{ Country } & \multicolumn{3}{|c|}{$\operatorname{AGC}(\%)$} & \multirow[t]{2}{*}{ No. ancestors } & \multirow[t]{2}{*}{ No. cultivars } & \multirow[t]{2}{*}{ Mean COP } & \multirow[t]{2}{*}{ Period } \\
\hline & 50 & 80 & 90 & & & & \\
\hline China & 35 & 190 & 339 & 339 & 651 & 0.02 & 1923-1995 \\
\hline Japan & 18 & 53 & $\mathrm{a}$ & 74 & 86 & 0.04 & 1950-1988 \\
\hline India & 5 & a & a & 76 & 66 & 0.05 & $1968-2000$ \\
\hline USA Total & 6 & 14 & 27 & 80 & 258 & 0.13 & $1947-1988$ \\
\hline USA North & 4 & 14 & 20 & 67 & a & 0.18 & \\
\hline USA South & 3 & 10 & 16 & 39 & a & 0.23 & \\
\hline Brazil & 5 & 9 & 12 & 26 & 69 & 0.16 & 1960-1984 \\
\hline Brazil $^{\mathrm{b}}$ & 4 & 9 & 13 & 60 & 444 & a & 1960-2009 \\
\hline
\end{tabular}

Sources: Hiromoto and Vello, 1986; Gizlice et al., 1994;.Cui et al., 2000a,b; Zhou et al., 2000; Bharadwaj et al., 2002.

Note: AGC, accumulated genetic contribution; COP, coefficient of parentage.

${ }^{a}$ Data not available.

${ }^{\mathrm{b}}$ Data from this study.

tion. Therefore, the objectives of this work are to (i) quantify the genetic base of 444 Brazilian soybean cultivars covering the years from 1943 to 2009, using COP obtained through pedigree records, (ii) quantify the changes that occurred in the genetic base over five periods (before 1971, 1971-1980, 1981-1990, 1991-2000 and 2001-2009), (iii) compare the genetic base of public and private soybean cultivars, and (iv) compare the Brazilian genetic base to that of other countries.

\section{Material and Methods}

The 444 cultivars soybean cultivars analyzed in this study were foreign, public, or private cultivars that were widely grown by farmers during certain periods. We made no distinction between specialty soybean, such as soybean for human consumption, and commodity soybean. Among the 444 cultivars 14 are public transgenic cultivars, which were included in this study. The pedigree data was obtained from various sources in the literature, from the Germplasm Resources Information Network and information from breeders. Ancestors were defined as founding stock with no known pedigree (Gizlice et al., 1994).

Malécot's COP $\left(f_{\mathrm{xy}}\right)$ was estimated based on the equation presented by Falconer and Mackay (1996), as follows

$$
f_{x y}=\frac{1}{4}\left(f_{A C}+f_{A D}+f_{B C}+f_{B D}\right)
$$

where $f$ is the COP between two cultivars $\mathrm{X}$ and $\mathrm{Y}$; $\mathrm{A}$ and $\mathrm{B}$ are the parents of cultivar $\mathrm{X}$ and $\mathrm{C}$ and $\mathrm{D}$ are parents of cultivar Y. We started by assembling the complete pedigrees of the Brazilian soybean cultivars, and traced them back to the ancestors, estimating the probability of the contribution that each ancestor made to each cultivar, that is, the COP between an ancestor and a cultivar. The following assumptions were made: (i) all the ancestors are independent, in other words, the COP between pairs of ancestors is $f=0$; (ii) in a cross, each parent contributes $50 \%$ of the genes; (iii) the cultivars, ancestors, and lines are all homozygous and homogenous; (iv) the COP between a plant selection and its antecedent was considered to be $f=1$; (v) the COP between a mutant and the original genotype was considered to be $f=1$. The calculations were performed using the computer software Microsoft Excel® (2003).

The relative genetic contribution (RGC) of different ancestors to a given selection was calculated by partitioning the genetic constitution of each cultivar, using the COP as an estimate. The mean RGC of the ancestors was calculated by averaging the RGC of that ancestor from all cultivars. The accumulated genetic contribution (AGC) is the sum, in decreasing order of importance, of the ancestral RGCs. The presence of an ancestor in a pedigree was determined as its frequency. The mean number of ancestors was determined by averaging the number of ancestors each cultivar had. The ancestor/cultivar ratio was also determined.

The cultivars were subdivided into groups according to the year of release or year of registration (when available) in Brazil. The timeframe was divided into five periods: before 1971, 1971-1980, 1981-1990, 1991-2000 and 2001-2009. The cultivars were also subdivided according to origin: public or private. The few cultivars that were developed abroad were excluded from this analysis. For each subgroup, all the above mentioned parameters were also calculated.

\section{Results and Discussion}

\section{Pedigrees}

Although over 700 cultivars were officially registered in Brazil in 2010, according to CultivarWeb, the database for the National Cultivar Registry from the Ministry of Agriculture, Livestock and Food Supply, we were only able to 
obtain the pedigrees for 444 cultivars. Due to the Variety Protection Act of 1997, many breeders have not made public the pedigrees of released cultivars, especially more recent ones. A few pedigrees deserve special attention. First, the cultivar FT-Cristalina originated from a natural cross between UFV-1 and an unknown parent. But based on morphological data, some breeders suggest that the unknown parent was Davis (Hiromoto and Vello, 1986), so this pedigree was used in the present work. The same authors reported that cultivar BR-9 (Savana) originated from the bulk LoB 74-2, with a probable pedigree being Davis x (Hill x PI 240664). Another important observation made is that morphological and molecular marker data have not supported the pedigree of the cultivar Lincoln (Gizlice et al., 1994;
Lorenzen et al., 1995), which appears in the genealogy of 28 Brazilian cultivars. So either the genealogy is incorrect, or the accessions maintained in the germplasm bank are not the real ancestors for Lincoln. Therefore, we chose to make Lincoln into an ancestral line.

\section{Overview of the genetic base}

The 444 cultivars analyzed traced back to 60 ancestors (Table 2). The four main ancestors (CNS, S-100, Roanoke and Tokyo), contribute more than half (55.3\%) to the genetic base, and CNS contributes alone with almost onefifth of the genetic base (19.2\%). Only the top 14 ancestors have a mean RGC of over $1 \%$, and their AGC is $92.4 \%$. Therefore, the 46 remaining ancestors contribute cumula-

Table 2 - Identification, mean RGC, AGC, frequency, origin of the ancestors of Brazilian soybean cultivars, mean RGC of ancestors for public and private cultivars, first progeny and CA.

\begin{tabular}{|c|c|c|c|c|c|c|c|c|c|}
\hline No. & Ancestors ${ }^{\mathrm{a}}$ & $\operatorname{RGC}^{\mathrm{b}}(\%)$ & $\operatorname{AGC}(\%)$ & Freq. & Origin $^{c}$ & $\begin{array}{c}\text { RGC (\%) } \\
\text { public }^{\mathrm{d}}\end{array}$ & $\begin{array}{c}\text { RGC (\%) } \\
\text { private }^{\mathrm{d}}\end{array}$ & $\begin{array}{l}\text { First } \\
\text { progeny }\end{array}$ & $\mathrm{CA}$ \\
\hline 1 & CNS (PI 548445) & 19.2 & 19.2 & 435 & Jiangsu, China & 19.1 & 19.1 & & \\
\hline 2 & S-100 (PI 548488) & 14.8 & 34.0 & 403 & Heilongjiang, China & 14.8 & 14.7 & & \\
\hline 3 & Roanoke (PI 548485) & 11.7 & 45.7 & 389 & Jiangsu, China & 11.3 & 12.8 & & \\
\hline 4 & Tokyo (PI 548493) & 9.6 & 55.3 & 423 & Kanagawa, Japan & 8.7 & 10.6 & & \\
\hline 5 & PI 54610 & 8.6 & 63.9 & 419 & Jilin, China & 8.1 & 9.5 & & \\
\hline 6 & PI $60406^{\mathrm{e}}$ & 5.0 & 68.9 & 280 & Fujian, China & 5.3 & 4.3 & $\begin{array}{l}\text { Improved Peli- } \\
\text { can (PI 548461) }\end{array}$ & $1 / 2$ \\
\hline 7 & Arksoy (PI 548438) & 4.3 & 73.2 & 261 & Pyongyang, North Korea & 4.0 & 5.6 & & \\
\hline 8 & Dunfield (PI 548318) & 4.2 & 77.4 & 312 & Jilin, China & 4.2 & 4.3 & & \\
\hline 9 & Haberlandt (PI 548456) & 4.2 & 81.6 & 309 & Pyongyang, North Korea & 4.2 & 4.3 & & \\
\hline 10 & Bilomi No. 3 (PI 240664) & 3.0 & 84.6 & 101 & Luzon, Philippines & 3.6 & 2.2 & & \\
\hline 11 & Biloxi (PI 548444) & 2.6 & 87.2 & 287 & Zhejiang, China & 2.8 & 2.2 & & \\
\hline 12 & Tanner (PI 548490) & 2.5 & 89.7 & 280 & Taiwan & 2.6 & 2.2 & & \\
\hline 13 & Palmetto (PI 548480) & 1.7 & 91.4 & 149 & Jiangsu, China & 1.8 & 1.3 & & \\
\hline 14 & Mogiana $^{e}$ & 1.0 & 92.4 & 54 & Brazil & 1.5 & 0.2 & $\begin{array}{l}\text { Industrial (PI } \\
\text { 628857) }\end{array}$ & $1 / 2$ \\
\hline 15 & $\begin{array}{l}\text { Pine Dell Perfection (PI } \\
\text { 548481) }\end{array}$ & 0.7 & 93.1 & 68 & Virginia, USA & 0.8 & 0.8 & & \\
\hline 16 & Laredo (PI 548463) & 0.7 & 93.8 & 73 & Shaanxi, China & 0.6 & 0.6 & & \\
\hline 17 & $\begin{array}{l}\text { Mammoth Yellow (PI } \\
\text { 548469) }\end{array}$ & 0.7 & 94.5 & 72 & Japan & 0.6 & 0.6 & & \\
\hline 18 & PI 274454 & 0.6 & 95.1 & 32 & Okinawa, Japan & 0.8 & 0.4 & & \\
\hline 19 & PI 171442 & 0.5 & 95.6 & 34 & Shaanxi, China & 0.4 & 0.9 & & \\
\hline 20 & Lincoln (PI 548362) & 0.4 & 96.0 & 28 & Illinois, USA & 0.2 & 0.7 & & \\
\hline 21 & Nanda (PI 548474) & 0.4 & 96.4 & 20 & Hwanghae Puk, North Korea & 0.5 & 0.1 & & \\
\hline 22 & Mandarin (PI 548378) & 0.3 & 96.7 & 19 & Heilongjiang, China & 0.3 & 0.2 & & \\
\hline 23 & FC 31745 & 0.3 & 97.0 & 26 & Unknown & 0.3 & 0.1 & & \\
\hline 24 & Er-hej-jan (PI 437654) & 0.3 & 97.3 & 20 & China & 0.3 & 0.1 & & \\
\hline 25 & Peking (PI 548402) & 0.2 & 97.5 & 47 & Beijing, China & 0.2 & 0.2 & & \\
\hline 26 & PI 80837 & 0.2 & 97.7 & 3 & Kanto and Tosan, Japan & 0.2 & 0.2 & & \\
\hline 27 & Soden-diazu (PI 229358) & 0.2 & 97.9 & 10 & Kanto, Japan & 0.3 & * & & \\
\hline 28 & Kedelee STB No. $452^{\mathrm{e}}$ & 0.2 & 98.1 & 2 & Unknown & 0.2 & 0.2 & $\begin{array}{l}\text { Planalto (PI } \\
628883)\end{array}$ & $1 / 2$ \\
\hline 29 & Aliança Preta ${ }^{\mathrm{e}}$ & 0.1 & 98.2 & 1 & Brazil & 0.2 & * & $\begin{array}{l}\text { IAC } 1(\mathrm{PI} \\
628842)\end{array}$ & $1 / 2$ \\
\hline
\end{tabular}


Table 2 (cont.)

\begin{tabular}{|c|c|c|c|c|c|c|c|c|c|}
\hline No. & Ancestors ${ }^{\mathrm{a}}$ & $\operatorname{RGC}^{\mathrm{b}}(\%)$ & $\operatorname{AGC}(\%)$ & Freq. & Origin $^{c}$ & $\begin{array}{l}\text { RGC (\%) } \\
\text { public }^{\mathrm{d}}\end{array}$ & $\begin{array}{l}\text { RGC (\%) } \\
\text { private }^{\mathrm{d}}\end{array}$ & $\begin{array}{l}\text { First } \\
\text { progeny }\end{array}$ & $\mathrm{CA}$ \\
\hline 30 & Chosen $^{\mathrm{e}}$ & 0.1 & 98.3 & 1 & Unknown & 0.2 & * & $\begin{array}{l}\text { Pioneira (PI } \\
417503)\end{array}$ & $1 / 2$ \\
\hline 31 & Asomusume (PI 423959) & 0.1 & 98.4 & 1 & Kumamoto, Japan & 0.2 & $*$ & & \\
\hline 32 & Tamahomare (PI 507327) & 0.1 & 98.5 & 1 & Japan, Kanto and Tosan & 0.2 & $*$ & & \\
\hline 33 & Patoka (PI 548400) & 0.1 & 98.6 & 16 & Heilongjiang, China & $\dagger$ & 0.2 & & \\
\hline 34 & Kuro Daizu (PI 81041) & 0.1 & 98.7 & 16 & Hokkaido, Japan & $\dagger$ & 0.2 & $\begin{array}{l}\text { Perry (PI } \\
548603)\end{array}$ & $1 / 2$ \\
\hline 35 & Amarela Comum ${ }^{\mathrm{e}}$ & 0.1 & 98.8 & 4 & Brazil & 0.1 & 0.1 & $\begin{array}{l}\text { Ivorá (PI } \\
628860)\end{array}$ & $1 / 4$ \\
\hline 36 & $\begin{array}{l}\text { Shinano mejiro (PI } \\
507244)\end{array}$ & 0.1 & 98.9 & 4 & Japan, Kanto and Tosan & 0.1 & 0.1 & & \\
\hline 37 & Howgyoku (PI 224270) & 0.1 & 99.0 & 4 & Hyogo, Japan & 0.1 & 0.1 & & \\
\hline 38 & Richland (PI 548406) & 0.1 & 99.1 & 12 & Jilin, China & $\dagger$ & 0.1 & & \\
\hline 39 & Kanro (PI 84928) & 0.1 & 99.2 & 3 & Pyongyang, North Korea & 0.1 & $*$ & & \\
\hline 40 & PLSO-41 (PI 346304) & 0.1 & 99.3 & 2 & India & $*$ & 0.3 & & \\
\hline 41 & $\begin{array}{l}\text { Mandarin (Ottawa) (PI } \\
\text { 548379) }\end{array}$ & 0.1 & 99.4 & 2 & Heilongjiang, China & 0.1 & $*$ & & \\
\hline 42 & Blyvoor (PI 374219) & 0.1 & 99.5 & 4 & North West, South Africa & $\dagger$ & 0.2 & & \\
\hline 43 & Kyushu $111^{\mathrm{e}}$ & 0.1 & 99.6 & 5 & Japan & 0.1 & * & $\begin{array}{l}\text { UFVTN 101, } \\
\text { UFVTN 102, } \\
\text { UFVTN 103, } \\
\text { UFVTN } 104\end{array}$ & $\begin{array}{c}1 / 1 \\
6\end{array}$ \\
\hline 44 & Kin-du (PI 157440) & 0.1 & 99.7 & 1 & South Korea & 0.1 & $*$ & & \\
\hline 45 & $\begin{array}{l}\text { Miyako White (PI } \\
\text { 227687) }\end{array}$ & 0.1 & 99.8 & 2 & Okinawa, Japan & 0.1 & $*$ & & \\
\hline 46 & PI 230979 & 0.1 & 99.9 & 1 & Tokyo, Japan & $*$ & 0.2 & & \\
\hline 47 & Shih-Shih (PI 262181) & $\dagger$ & 99.9 & 2 & Japan & 0.1 & $*$ & & \\
\hline 48 & PI 159925 & $\dagger$ & 99.9 & 5 & Lima, Peru & 0.1 & $*$ & & \\
\hline 49 & PI 88788 & $\dagger$ & 99.9 & 6 & Liaoning, China & $\dagger$ & $\dagger$ & & \\
\hline 50 & $\begin{array}{l}\text { Goyou Kurakake (PI } \\
86023)^{\mathrm{e}}\end{array}$ & $\dagger$ & 99.9 & 5 & Hokkaido, Japan & $\dagger$ & $*$ & $\begin{array}{l}\text { UFVTN } 101, \\
\text { UFVTN } 102, \\
\text { UFVTN } 103, \\
\text { UFVTN } 104\end{array}$ & $\begin{array}{c}1 / 3 \\
2\end{array}$ \\
\hline 51 & Shirohadaka (PI 86490) & $\dagger$ & 99.9 & 1 & Akita, Japan & $\dagger$ & $*$ & & \\
\hline 52 & PI $71506^{\mathrm{e}}$ & $\dagger$ & 99.9 & 1 & Jiangsu, China & $\dagger$ & * & $\begin{array}{l}\text { Hutcheson (PI } \\
\text { 518664) }\end{array}$ & $1 / 4$ \\
\hline 53 & $\mathrm{~V}-148^{\mathrm{e}}$ & $\dagger$ & 99.9 & 1 & Unknown & $\dagger$ & * & $\begin{array}{l}\text { IAC } 14(\mathrm{PI} \\
628849)\end{array}$ & $1 / 8$ \\
\hline 54 & A.K. Harrow (PI 548298) & $\dagger$ & 99.9 & 2 & China & $\dagger$ & * & & \\
\hline 55 & No. $171^{\mathrm{e}}$ & $\dagger$ & 99.9 & 1 & China & $\dagger$ & $*$ & $\begin{array}{l}\text { Capital (PI } \\
\text { 548311) }\end{array}$ & $1 / 2$ \\
\hline 56 & GTS $-40-3-2^{\mathrm{f}}$ & $\dagger$ & 99.9 & 14 & USA & $\dagger$ & $*$ & & \\
\hline 57 & TGX-342-351D & $\dagger$ & 99.9 & 3 & Nigeria & $\dagger$ & $*$ & BRS 214 & $\begin{array}{c}1 / 6 \\
4\end{array}$ \\
\hline 58 & I-Higo-Wase (PI 205085) & $\dagger$ & 99.9 & 5 & Japan & $\dagger$ & $*$ & & \\
\hline 59 & PI 90763 & $\dagger$ & 99.9 & 1 & Beijing, China & $\dagger$ & $*$ & & \\
\hline 60 & Mukden (PI 548391) & $\dagger$ & 100.0 & 2 & Liaoning, China & $\dagger$ & * & & \\
\hline
\end{tabular}

Note: RGC, relative genetic contribution; AGC, accumulated genetic contribution; CA, contribution from ancestor to first progeny.

${ }^{a}$ PI numbers from GRIN (Germplasm Resources Information Network) are provided when available.

$\mathrm{b}_{\uparrow} \uparrow$ indicates that this ancestor contributes less than $0.1 \%$ to the genetic base.

${ }^{\mathrm{c}}$ The primary geographical origins are China, Japan, North Korea and South Korea; the secondary ones are other locations mentioned (based on GRIN (Germplasm Resources Information Network)).

$\mathrm{d}_{*}$ indicates that the ancestor does not contribute to the public or private pool.

${ }^{e}$ no known seed sources available.

${ }^{\mathrm{f}}$ Developed through particle gun bombardment of line A5403 (PI 556861). 
tively only $7.6 \%$ to the genetic base. For comparison, Hiromoto and Vello (1986) reported 26 ancestors for a group of 69 cultivars, and the AGC of the top four ancestors was $48.2 \%$. These were the same top four ancestors found in this study, but with a different order. These results indicate that the genetic base of Brazilian soybean is still narrow, despite the incorporation of new ancestors.

For those ancestors that no longer exist (or we do not know from where seeds are available) we provide a first progeny, as defined by Gizlice et al. (1994), for screening options due to the missing ancestor. For the top 20 ancestors, only two are unavailable (PI 60406 and Mogiana).

On average, there were 10.52 ancestors for each cultivar, ranging from 2 to 23 . However, this increase must be taken with caution, because it is mainly due to the incorporation of low-contribution ancestors. For example, the mean number of ancestors for the total period is 10.52 (Table 3), a high value when compared to the Chinese (3.79) and Japanese (3.20) values (Cui et al., 2000a; Zhou et al., 2000 ). But when we only consider ancestors with RGCs of $5 \%$ and $10 \%$ to cultivars, this number drops to 7.11 and 4.08 , respectively (Figure 1), demonstrating that many ancestors have only small contributions.

The frequency of ancestors also demonstrates how narrow the genetic base is. The main ancestor, CNS, is present in the pedigree of 435 cultivars $(98.0 \%)$. The other top ancestors (S-100, Roanoke and Tokyo) also have very high frequencies. CNS and S-100 are the most common ancestors because their cross resulted in cultivar Lee and the line D49-2491, a sister of Lee and an ancestor of Bragg. Lee and Bragg were used as parents in many early cultivars developed in Brazil. They are present in 118 and 135 cultivars, respectively. As the RGC decreases so does the frequency, both being highly correlated $(r=0.88)$, to the extreme that some ancestors (11) only contribute to one cultivar. Notwithstanding, some ancestors have low RGCs but have higher than expected frequencies. This usually occurs because the ancestor was used in backcrosses to incorporate

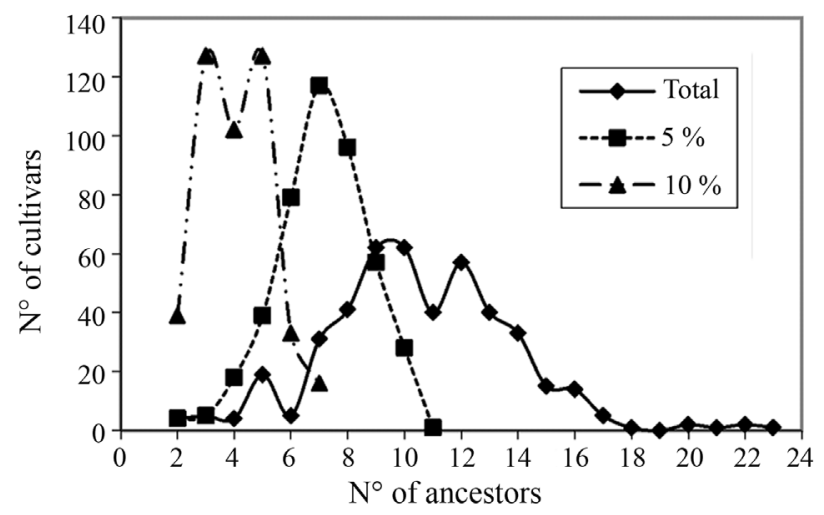

Figure 1 - Number of ancestors that contribute to cultivars irrespective of RGC (circle), with RGC equal to or greater than 5\% (square) and 10\% (triangle). simple traits. One clear example is the ancestor GTS-403-2, which was used to incorporate the CP4 EPSPS gene, confering resistance to glyphosate, into the 14 transgenic cultivars analyzed here (Sneller, 2003).

As seen above, most of the ancestors have very low mean RGCs. We believe this occurs because breeders usually use new lines as parents to introduce specific genes, usually involving backcrossing. Therefore, parents used as gene donors through backcrossing lead to an increase in the number of ancestors, but do not contribute significantly to increase the genetic base of the cultivated species.

A database search on GRIN (Germplasm Resources Information Network) allowed us to identify a few notable characteristics of some ancestors (Table 4). Some lowcontributing ancestors (but not all) may have been incorporated into the genetic base for these traits. For example, the ancestor I-Higo-Wase (PI 205085), which has a mean RGC of $0.0036 \%$ and contributes to only five cultivars, has the lx3 allele, which confers an absence of lipoxygenase- 3 in seeds. This ancestor was used to incorporate this trait into five soybean cultivars developed for human consumption. Another ancestor used in this manner is PI 88788, with a mean RGC of $0.0299 \%$. This ancestor is resistant to soybean cist nematode, races 3 and 14. Shirohadaka (PI 86490), with the small seed trait, was used to incorporate this characteristic into a cultivar aimed at producing natto, a fermented soybean dish appreciated in Japan.

The geographical origin of the 60 ancestors is provided (Table 2). The primary geographical origins were considered to be the countries where soybean may have originated, or are considered as centers of diversity (based on information from GRIN). When the primary geographical origin was unknown, we used the secondary geographical origin, which is the country where the ancestor was collected or developed. When no information was available, the origin was left as unknown. Most of the ancestors are from Asia (78\%), mainly from China and Japan. One assumption made in this work is that ancestors are unrelated; however, this may not be the case, especially with ancestors originating in the same area (e.g. Jiangsu, China). Therefore, the relationship between ancestors and cultivars is probably underestimated and the real genetic base may be narrower than the estimated genetic base (Hiromoto and Vello, 1986; Mikel et al., 2010). Indeed, Gizlice et al. (1993), using multivariate analysis of ten traits, estimated genetic similarity coefficients for 14 ancestors of North American soybean cultivars, which ranged from 0.00 to 0.88 , demonstrating that some are indeed similar and may have some degree of relatedness.

\section{Period analysis}

The results from the different periods (Table 3 ) show that as soybean grew in importance in Brazil the number of cultivars increased. Before 1971 there were 17 cultivars and in the last period (2001-2009) there were 116 cultivars, 


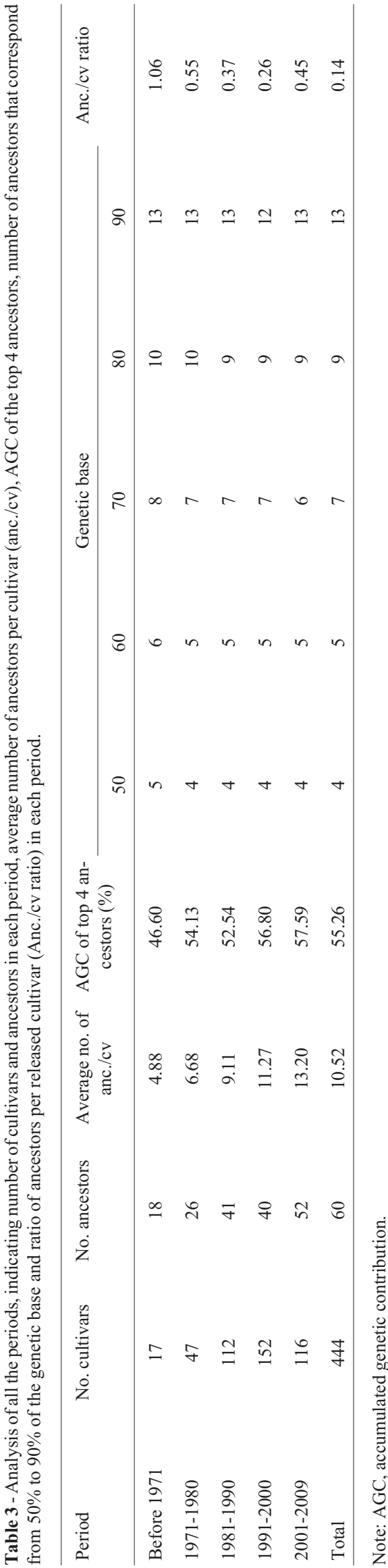

not counting cultivars with unavailable pedigrees. We also clearly detect an increase in the number of ancestors over time, also supported by an increase in the mean number of ancestors per cultivar, increasing from 4.88 to 13.20 . But here one must take into account that many ancestors have only low contributions (Figure 1).

The genetic base of Brazilian soybean cultivars has decreased over the past few decades (Table 3). The top four ancestors in each period were always CNS, S-100, Roanoke and Tokyo, and with the exception of CNS, which remained as the ancestor with the highest RGC throughout all periods, the ranking of the other three changed. In the final period (2001-2009), CNS alone represented more than one-fifth of the genetic base $(20.7 \%)$. These results also support the fact that the genetic base has decreased over time. Delannay et al. (1983), studying the North American genetic base also observed a similar effect, with the number of ancestors increasing over time, but accompanied by an increase of the main ancestors' RGC. On the other hand, Cui et al. (2000a) observed that the Chinese soybean genetic base increased over time, with the incorporation of new ancestors and the RGC of ancestors became more uniformly distributed.

\section{Public vs. private cultivars}

Of the 444 cultivars analyzed, 301 were of public and 112 of private origin, and 31 were of foreign or unknown origin. The public cultivars had 58 ancestors (Table 2), close to the total number of ancestors (60), with only two ancestors contributing exclusively to the private cultivars, PI 346304 and PI 230979. The top four ancestors for public cultivars are identical to the total ancestors of the total group of cultivars, and their AGC is $53.9 \%$. The top 13 ancestors for this group contributed with $90.5 \%$ to the genetic base, and are also the same top 13 ancestors for the total group of cultivars, with minor changes in rank.

On the other hand, the private cultivars had only 37 ancestors. This low number of ancestors may reflect the lower number of cultivars in this group and the use of a restricted number of cultivars in private breeding programs. However, the genetic base of this group does not significantly differ from the public and the total group. For example, the top four ancestors for private cultivars are the same as those for the public group and general group of cultivars, CNS, S-100, Roanoke and Tokyo in this order, but with a slightly higher AGC (57.2\%). Also, the top 13 ancestors for this group, which represent $93.1 \%$ of the genetic base, are also the same ancestors for the other two groups, with minor changes in rank.

\section{Comparison with other genetic bases}

When comparing the results from this study to the soybean genetic bases of other countries (Table 1), one can see that Brazil still has a very narrow genetic base. Hiromoto and Vello (1986) reported that six of the main ances- 
Table 4 - Ancestors, identified by name and number based on mean RGC and notable traits.

\begin{tabular}{|c|c|c|}
\hline No. & Ancestors & Some notable traits ${ }^{\mathrm{a}}$ \\
\hline 1 & CNS (PI 548445) & $\begin{array}{l}\text { Rj2 allele, inefficient nodulation of } \mathrm{b} 7, \mathrm{~b} 14 \text { and b122 Rhizobium strains; Rps } 2 \text { allele, resistant to Phy- } \\
\text { tophthora rot, races } 1 \text { and } 2 ; \text { Rpv1 allele, resistant to Peanut Mottle Vírus, M-2; rxp allele, resistant to } \\
\text { bacterial pustule. }\end{array}$ \\
\hline 2 & S-100 (PI 548488) & Allele $N c l 1$, chloride exclusion; allele Dt1, indeterminate growth; resistant to Phytophthora rot race 1. \\
\hline 3 & Roanoke (PI 548485) & Resistant to frog eye leaf spot. \\
\hline 4 & Tokyo (PI 548493) & Allele $R s v 1-t$, resistant to Soybean Mosaic Virus, strains G1, G2, G4, G5 and G6. \\
\hline 5 & PI 54610 & Resistant to frog eye leaf spot races 2 to 5 \\
\hline 7 & Arksoy (PI 548438) & Allele Rps1-c, resistant Phytophthora rot, races 1 to 3, 6 to $11,13,15,17$ and 21 \\
\hline 9 & Haberlandt (PI 548456) & Resistant to frog eye leaf spot \\
\hline 10 & Bilomi No. 3 (PI 240664) & Long juvenile period \\
\hline 18 & PI 274454 & Resistant to insects (e.g. Diabrotica speciosa and Cerotoma $\mathrm{sp.})^{\mathrm{b}}$ \\
\hline 19 & PI 171442 & Allele Rps3; resistant Phytophthora rot, races 1 to 5, 8, 9, 11, 13, 14, 16, 18 \\
\hline 23 & FC 31745 & Allele Rps1-b; resistant Phytophthora rot, races 1,3 to 9,13 to $15,17,18,21,22$ \\
\hline 24 & Er-hej-jan (PI 437654) & Resistant to soybean cyst nematode (alleles $r g h 1$ and $\operatorname{Rgh} 4)^{\mathrm{c}}$ \\
\hline 25 & Peking (PI 548402) & Resistant to soybean cyst nematode (alleles $r h g 1$ to 3 and $R h g 4)^{\mathrm{c}}$ \\
\hline 26 & PI 80837 & Resistant to Phomopsis spp. ${ }^{\text {d. }}$; resistant to Cercospora kikuchii ; allele $P d 1$ dense pubescence ${ }^{\mathrm{f}}$ \\
\hline 27 & Soden-diazu (PI 229358) & Resistant to insects (e.g. Diabrotica speciosa and Cerotoma sp. $)^{\mathrm{b}, \mathrm{g}}$ \\
\hline 31 & Asomusume (PI 423959) & Resistant to Phytophthora rot, race 1 \\
\hline 33 & Patoka (PI 548400) & Allele $r c s 1$, susceptible to frog eye leaf spot, race 1 . \\
\hline 36 & Shinano mejiro (PI 507244) & Resistant to Phytophthora rot races 1 to 8,17 and 25 \\
\hline 40 & PLSO-41 (PI 346304) & Resistant to CCMV (Cowpea Chlorotic Mottle Vírus) \\
\hline 43 & Kyushu 111 & Triple null for lipoxygenases 1,2 and 3 (alleles $l \times 1, l \times 2$, and $l \times 3$ ) \\
\hline 44 & Kin-du (PI 157440) & Allele $t i$, absence of Kunitz trypsin inhibitor ${ }^{\mathrm{f}}$ \\
\hline 45 & Miyako White (PI 227687) & Resistant to insects ${ }^{\mathrm{h}}$ \\
\hline 46 & PI 230979 & Resistant to Phytophthora rot, races 1 to 4 \\
\hline 47 & Shih-Shih (PI 262181) & Resistant to Phytophthora rot, races 1, 3 and 4; vegetable and conventional soybean \\
\hline 48 & PI 159925 & Allele $j$, long juvenile period \\
\hline 49 & PI 88788 & Resistant to soybean cyst nematode, races 3 and $14^{c}$ \\
\hline 50 & Goyou Kurakake (PI 86023) & Allele $l \times 2$, absence of lipoxygenase- 2 \\
\hline 51 & Shirohadaka (PI 86490) & Small seeds \\
\hline 52 & PI 71506 & Resistant to soybean aphid (Aphis glycines) ${ }^{\mathrm{i}}$; poor germination under high temperatures ${ }^{\mathrm{j}}$ \\
\hline 56 & GTS-40-3-2 & Source of CP4 EPSPS gene $\mathrm{e}^{\mathrm{k}}$ \\
\hline 58 & I-Higo-Wase (PI 205085) & Allele $l \times 3$, absence of lipoxygenase- 3 \\
\hline 59 & PI 90763 & Resistant to soybean cyst nematode, races 1 to 3 and $5^{\mathrm{c}}$ \\
\hline 60 & Mukden (PI 548391) & Resistant to Phytophthora rot (allele Rps 1), races 1, 2, 10,13, 16 \\
\hline
\end{tabular}

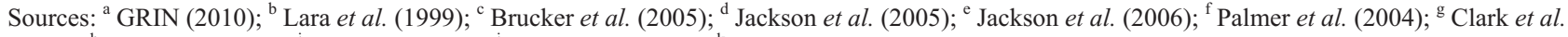
(1972); ${ }^{\text {h }}$ Rose et al. (1989); ${ }^{\mathrm{i}}$ Hill et al. (2004); ${ }^{\mathrm{j}}$ Smith et al. (2008); ${ }^{\mathrm{k}}$ Parrott and Clemente (2004).

Note: RGC, relative genetic contribution.

tors of that time were shared with the North American soybean genetic base. In this study, a total of 26 ancestors were shared, based on Gizlice et al. (1994). When only considering the main ancestors of both countries, then the Brazilian and North American soybean genetic bases share only six ancestors (CNS, S-100, Roanoke, Tokyo, PI 54610 and Dunfield), the same number as reported by Hiromoto and Vello (1986). Another point is that the top five ancestors described here (CNS, S-100, Roanoke, Tokyo and PI
54610) are the exact same top five ancestors for the soybean genetic base of the southern USA. This, as Hiromoto and Vello (1986) argue, is due to the fact that the Brazilian soybean genetic base was partially derived from cultivars from this part of the USA.

When compared to the Chinese (Cui et al., 2000a) and Japanese (Zhou et al., 2000) genetic base, Brazil apparently shares only 9 (S-100, Peking, Mandarin (Ottawa), A.K. Harrow, CNS, Richland, Mukden, Lincoln and Man- 
darin) and 7 (Kuro Daizu, Mandarin (Ottawa), CNS, S-100, A.K. Harrow, PI 54610 and Tokyo) ancestors, respectively, based on ancestors names. And these shared ancestors have very low contributions to soybean cultivars from China and Japan. Therefore, as reported previously by Yamanaka et al. (2007), the Brazilian gene pool is distinct from the Chinese and Japanese gene pools, and they can represent sources for increasing the Brazilian soybean genetic base. However, since ancestor names and designations can vary or become lost, it is likely that the Brazilian, Chinese and Japanese genetic bases share more ancestors than currently observed.

\section{Breeding implications}

Based on the data presented here, breeders interested in expanding the genetic base of their programs may choose parents with the most divergent pedigrees from the present genetic base. As shown above, cultivars from Japan and China may be good choices because of the difference between their genetic bases and Brazil's genetic base. Cui et al. (2000a) reported that Chinese breeders have used this approach with some success, incorporating US cultivars into Chinese breeding programs, also because of their genetic divergence.

Another potential use for the ancestors of a genetic base is described by Carter Jr et al. (2004). They propose that breeders can screen the ancestors for a given trait, instead of the cultivars, because there are many more cultivars than ancestors. After the identification of the ancestors with a particular trait, the cultivars with the highest probability of having that trait can be identified, based on their RGC with the identified ancestors. This would allow researchers to screen much more rapidly for a given trait and would also save valuable resources in cases where the trait is difficult or expensive to evaluate. This approach has been used to screen many traits in the North American genetic base, including foliar resistance to ozone injury (Burkey and Carter Jr, 2008) and tolerance to herbicides (Carter Jr et al., 2004).

\section{Acknowledgments}

The authors would like to thank the reviewers for their valuable comments. This received financial support and scholarships from CAPES (Coordination for the Improvement of Higher Education Personnel) and $\mathrm{CNPq}(\mathrm{Na}-$ tional Council for Scientific and Technological Development).

\section{References}

Bharadwaj CH, Satyavathi CT, Tiwari SP and Karmakar PG (2002) Genetic base of soybean (Glycine max) varieties released in India as revealed by coefficient of parentage. Indian J Agric Sci 72:467-469.

Burkey KO and Carter Jr TE (2008) Foliar resistance to ozone injury in the genetic base of U.S. and Canadian soybean and prediction of resistance in descendent cultivars using coefficient of parentage. Field Crops Res 111:207-217.

Brucker E, Carlson S, Wright E, Niblack T and Diers B (2005) Rhgl alleles from soybean PI 437654 and PI 88788 respond differentially to isolates of Heterodera glycines in the greenhouse. Theor Appl Genet 111:44-49.

Carter Jr TE, Nelson RL, Sneller CH and Cui Z (2004) Genetic diversity in soybean. In: Boerma HR and Specht JE (eds) Soybeans: Improvement, Production and Uses. $4^{\text {th }}$ edition. American Society of Agronomy, Crop Science Society of America and Soil Science Society of America, Madison, pp 302-416.

Clark WJ, Harris FA, Maxwell FG and Hartwig EE (1972) Resistance of certain soybean cultivars to bean leaf beetle, striped blister beetle and bollworm. J Econ Entomol 65:1669-1672.

Cui Z, Carter Jr TE and Burton JW (2000a) Genetic base of 651 Chinese soybean cultivars released during 1923 to 1995. Crop Sci 40:1470-1481.

Cui Z, Carter Jr TE and Burton JW (2000b) Genetic diversity patterns in Chinese soybean cultivars based on coefficient of parentage. Crop Sci 40:1780-1793.

Delannay X, Rodgers DM and Palmer RG (1983) Relative genetic contributions among ancestral lines to North American soybean cultivars. Crop Sci 23:944-949.

Falconer DS and Mackay TFC (1996) Small populations III: pedigreed populations and close inbreeding. In: Falconer DS and Mackay TFC (eds) Introduction to Quantitative Genetics. 4th edition. Longman, Essex, pp 82-99.

Gizlice Z, Carter TE and Burton JW (1993) Genetic diversity in North American soybean: I. multivariate analysis of founding stock and relation to coefficient of parentage. Crop Sci 33:614-620.

Gizlice Z, Carter TE and Burton JW (1994) Genetic base for North American public soybean cultivars released between 1947 and 1988. Crop Sci 34:1143-1151.

Hill CB, Li Y and Hartman GL (2004) Resistance to the soybean aphid in soybean germplasm. Crop Sci 44:98-106.

Hiromoto DM and Vello NA (1986) The genetic base of Brazilian soybean (Glycine max (L.) Merrill) cultivars. Brazil J Genet 9:295-306.

Jackson EW, Fenn P and Chen P (2005) Inheritance of resistance to Phomopsis seed decay in soybean PI 80837 and MO/PSD-0259 (PI 562694). Crop Sci 45:2400-2404.

Jackson EW, Fenn P and Chen P (2006) Inheritance of resistance to purple seed stain caused by Cercospora kikuchii in PI 80837 soybean. Crop Sci 46:1462-1466.

Lara FM, Elias JM, Baldin ELL and Barbosa JC (1999) Feeding preference of Diabrotica speciosa (Germ.) and Cerotoma sp. for soybean genotypes. Sci Agric 56:947-951.

Lorenzen LL, Boutin S, Young N, Specht JE and Shoemaker RC (1995) Soybean pedigree analysis during map-based molecular markers. I: Tracking RFLP markers in cultivars. Crop Sci 35:1326-1336.

Mikel MA, Diers BW, Nelson RA and Smith HH (2010) Genetic diversity and agronomic improvement of North American soybean germplasm. Crop Sci 50:1219-1229.

Palmer RG, Pfeiffer TW, Buss GR and Kilen TC (2004) Qualitative genetics. In: Boerma HR and Specht JE (eds) Soybeans: Improvement, Production and Uses. 4th edition. American Society of Agronomy, Crop Science Society of America and Soil Science Society of America, Madison, pp 137-233. 
Parrott WA and Clemente TE (2004) Transgenic soybean. In: Boerma HR and Specht JE (eds) Soybeans: Improvement, Production and Uses. 4th edition. American Society of Agronomy, Crop Science Society of America and Soil Science Society of America, Madison, pp 137-233.

Rose RL, Sparks TC and Smith CM (1989) The influence of resistant soybean (PI 227687) foliage and coumestrol on the metabolism of xenobiotics by the soybean looper, Pseudoplusia includens (Walker). Pestic Biochem Physiol 34:17-26.

Smith JR, Mengistu A, Nelson RL and Paris RL (2008) Identification of soybean accessions with high germinability in high-temperature environments. Crop Sci 48:2279-2288.

Sneller CH (1994) Pedigree analysis of elite soybean lines. Crop Sci 34:1515-1522.

Sneller CH (2003) Impact of transgenic genotypes and subdivision on diversity within elite North American soybean germplasm. Crop Sci 43:409-414.

Yamanaka N, Sato H, Yang Z, Xu DH, Catelli LL, Binneck E, Arias CAA, Abdelnoor RV and Nepomuceno AL (2007) Genetic relationships between Chinese, Japanese, and Bra- zilian soybean gene pools revealed by simple sequence repeat (SSR) markers. Genet Mol Biol 30:85-88.

Zhou X, Carter Jr TE, Cui Z, Miyazaki S and Burton JW (2000) Genetic base of Japanese soybean cultivars released during 1950 to 1988. Crop Sci 40:1794-1802.

\section{Internet Resources}

Conab - National Supply Company, http://www.conab.gov.br (January 16, 2013).

CultivarWeb - Ministry of Agriculture, Livestock and Supply (MAPA)

http://extranet.agricultura.gov.br/php/snpc/cultivarweb/cult ivares_registradas.php (September 24, 2010).

Germplasm Resources Information Network (GRIN, 2010) http://www.ars-grin.gov/cgi-bin/npgs/html/crop.pl?51 (September 8, 2010).

Associate Editor: Márcio de Castro Silva Filho

License information: This is an open-access article distributed under the terms of the Creative Commons Attribution License, which permits unrestricted use, distribution, and reproduction in any medium, provided the original work is properly cited. 